Relations industrielles

Industrial Relations

\title{
Éric Tucker, Administering Danger in the Workplace: The Law and Politics of Occupational Health and Safety Regulation in Ontario 1850-1914
}

\section{Leigh West}

Volume 46, numéro 3, 1991

URI : https://id.erudit.org/iderudit/050711ar

DOI : https://doi.org/10.7202/050711ar

Aller au sommaire du numéro

Éditeur(s)

Département des relations industrielles de l'Université Laval

ISSN

0034-379X (imprimé)

1703-8138 (numérique)

Découvrir la revue

Citer ce compte rendu

West, L. (1991). Compte rendu de [Éric Tucker, Administering Danger in the Workplace: The Law and Politics of Occupational Health and Safety Regulation in Ontario 1850-1914]. Relations industrielles / Industrial Relations, 46(3),

678-679. https://doi.org/10.7202/050711ar

Tous droits réservés @ C Département des relations industrielles de l'Université Laval, 1991
Ce document est protégé par la loi sur le droit d'auteur. L’utilisation des services d’Érudit (y compris la reproduction) est assujettie à sa politique d'utilisation que vous pouvez consulter en ligne.

https://apropos.erudit.org/fr/usagers/politique-dutilisation/ 
Administering Danger in the Workplace: The Law and Politics of Occupational Health and Safety Regulation in Ontario 1850-1914, by Eric Tucker, University of Toronto Press, 1990,301 p., ISBN 0-8020-5855-8 (cloth) ISBN 0-8020-6765-4 (paper)

In looking backwards at a 64 year span of occupational health and safety history (1850-1914), Eric Tucker documents, in rich detail, the struggle of industrial workers to improve their workplaces. It is a struggle that goes on to-day, and in fact, the contemporary politics and problems of occupational health and safety would appear to be strikingly and frustratingly similar to the problems confronting our first factory workers. Tucker documents the passage of the first pieces of legislation directly regulating the workplace and which, to some extent, displaced regulation by market forces. Tucker's historical perspective on the problems of the workplace is an attempt to expose the underlying dynamics operating in a capital - welfare state which tend to perpetuate the exploitation of workers health and safety even where protective legislation exists.

As Tucker acknowledges, the focus of the book is very narrow. It takes a chronological look at the emergence of a regulatory scheme designed to protect factory and railway workers. Only a small percentage of workers in this time frame actually worked in factories (between $20 \%-25 \%$, the majority of workers being in agricultural labour) and in fact, in the early years there was only a limited number of industrial workplaces but it was for these workers and workplaces that the new occupational health and safety legislation was designed. In utilizing the historical in-depth approach Tucker is able to range across academic disciplines and thereby raise issues of more general importance concerning the impact of industrial capitalism.

In so doing, he relies heavily on a Marxist or neo-Marxist framework to isolate principles which form the basis of a theory of regulation. He concludes that while the enactment of health and safety legislation was a victory for workers politically, the regulatory system itself did little to improve the health and safety of the workers. The bulk of the book sets out to tell us why.

Prior to regulation, the courts had the task of arbitrating health and safety disputes brought by injured workers. Compensation schemes did not yet exist and the regulation of workplace risk was left to the judiciary. An early section of the book describes the judicial treatment of the unfortunate workers who ended up in court. Tucker describes how the judiciary chose the British model of legal relations which favoured capitalism at the expense of labour. This trend was not surprising, claims Tucker, given the values, professional backgrounds and interests of the men who were on the Bench. Biographical accounts of four of the leading judges are presented to give a partial explanation of how courts failed workers. This section also takes into account Galanter's ${ }^{1}$ theory of why courts have not been the catalyst for social change and why the "haves" always come out ahead.

Another section deals in great detail with the creation of the first industrial inspectorate after the initial legislation was enacted in 1886 . It outlines the roots of the ultimate failure of the inspection system both in the interpretation and the enforcement of the new law. The lack of government commitment was revealed in the failure to devote adequate resources to inspection, and this in turn led to the failure to adequately enforce the law. From the beginning, the different philosophies of labour and management with respect to the impositions of real sanctions and the use of prosecution as a means of obtaining compliance was problematic. As it evolved, inspectors were not to "police" workplaces but were to mediate disputes and persuade employers to comply with the Act. Management prevailed, and prosecutions were relegated for use only as a last resort. The disagreement about prosecutions could then be seen

1 Mark Galanter, "Why the "Haves" Come Out Ahead: Speculations on the Limits of Legal Change", Law and Society Review, Vol. 9, 1974, p. 95. 
as an administrative rather than as the operational and central problem that it was. Workers themselves were often blamed for their own injuries. In short, the law was interpreted and the level of risk adjusted according to the prevailing views of industrial management and enforcement was subordinated to the imperatives of capitalism.

Disappointingly, however, Tucker backs away from any analysis of whether or not the new legislation had an impact on accident and injury rates. Impact studies are virtually nonexistent even today and a baseline study of any differences in the injury rates by the introduction of the new legislation would have been instructive. Tucker misses an opportunity to do such an analysis at the time the first inspectors were appointed. After the new Act came into effect, three inspectors were named, one of whom was the representative of labour and who carried out the enforcement portions of the Act more diligently than did the management oriented inspector. Tucker concludes however, that the data is too crude to allow for comparisons to be made as to the relative impact on the workplace that might have resulted from the stricter enforcement of the Act by the more rigorous inspector.

In perhaps the most interesting section of the book Tucker analyzes and examines various theoretical formulations which he believes explain "why the workers got the Act they got". He includes in his analysis capture theories, theories of class struggle, theories about the impact of public opinion on the politics of the day and feminist theories on the treatment of women in the workplace. In his discussion of the development of industrial capitalism he relies on Marxist frameworks and notions of labour as a commodity. This section particularly raises interesting modern questions about such issues as the class-conflict model, managerial rights and prerogatives, workplace democracy and gender-based protective policies.

Reading this book provides a good overview of the dynamics of the politics of occupational health and safety. For those interested in the question of empowering oppressed groups, the material provides a focus and a few ideas about power relationships in the context of a capitalist society. The problems raised in these pages are very important and difficult ones in a modern state.

Leigh WEST

University of Windsor 